\title{
Influence of Women Participation on Sustainability of the Community Conservation Project Implemented by Jaldesa Community Conservancy in Marsabit County, Kenya
}

\author{
Rufo Roba and Reuben Wambua Kikwatha
}

\section{ABSTRACT}

Biodiversity conservation is a new paradigm shift in the management of Community wildlife resources as a tool to sustainable growth of the economy, improved livelihood, and preservation of nature. The study established the role of women participation in projects and the sustainable wildlife conservation project at Jaldesa community in Marsabit County, Kenya. The study utilized four variables that included women in decision making, control \& access to resources, project implementation and capacity building of women leaders \&sustainable Jaldesa community conservation project. The design approach in the study was a cross-sectional survey having a mixed mode of research methods characterized with qualitative and quantitative. The Participatory and Ecological Feminism Theory were significant for the study. The probability and non-probability sampling were utilized to obtain sample size of $\mathbf{4 4 3}$ samples drawn from a target population of 19,860. Pilot study was obtained using a fraction of the sample. The reliability analysis was attained through Cronbach's Alpha coefficient of $\alpha>0.7$. The research instrument was utilized. The researcher herself collected the Primary data using questionnaires and focus group discussions as research instrument. Descriptive and inferential statistics were analyzed with SPSS version 25. The Pearson's moment correlation concluded that Access \& Control of Resources, Capacity Building, Decision Making and Implementation has a significant influence on the sustainable conservation of Jaldesa community projects in Marsabit County, Kenya and there is a strong relationship. The study recommends that the authorities at national and county government of Marsabit County involve women in decision making, leadership roles, attend meeting, be party to decisions made by the conservancy board and making them well versed on the decision-making processes. Also, recommends that women manage, control, and have full access to resources through financial liberty, have voice on access to and control of resources and giving them right to resources and ownership.

Keywords: Access \& Control of Resources, Capacity building, Decision making, Participation, Resource contribution and Sustainability.
Submitted : May26, 2021

Published: June 19, 2021

ISSN: 2507-1076

DOI: $10.24018 /$ ejbmr.2021.6.3.898

Rufo Roba*

University of Nairobi, Kenya.

(e-mail:rushruffo@gmail.com)

Reuben Wambua Kikwatha

University of Nairobi, Kenya.

(e-mail: kikwathar@yahoo.com)

\section{INTRODUCTION}

In the global perspectives, rising inhabitants and scientific encroachment have strained the environmental natural resources in most Countries. Over-exploitation of any country's Natural assets reminiscent of water bodies, land units, air, and natural fuel has resulted in dilapidation of resources with impacts to land pollution, urban pressure, air pollution, soil degradation and deforestation. Consequently, the environmental conservation is vital to enhance natural build up for future generations. According to [1], it is apparent that the progress towards women participation in the sustainability of community conservancy projects has encountered obstacles at the institutional level in all countries of the world.
Globally, conferences for women on natural Diversity strengthen the biological protection and preservation of biomes in the society. The conventions are avenue for women to add their voice and fully participate in policy development and implementation of wildlife conservation process [2]. The role of women in conservancy is vital in policy making for wildlife resources and it creates an avenue for women leaders to showcase their leadership skills in shaping biodiversity legal framework in the community.

Women's participation in community-based development projects is conceptualized in this study as being women's active involvement in the community. According to the Kenya Wildlife Conservancies Association, women involved in the 102 community conservancies management as at the year 2019 are eight female managers, two female chairpersons and there are 6 community conservancies with 
women enterprise project [3]. The ultimate goal of women leadership in Wildlife conservancy is to enhance sustainable community participation and capacity building of women population sensitive to wildlife resources.

In Kenya,[4] observed that Amboseli National Park has surrounding land is known for wildlife dispersion and a breeding ground for community conservation initiatives. In another discourse, [5] observed that Amboseli, Tsavo West Chuylu Hills Parks serves as Wildlife Migratory routes to a tune of $70 \%$ of the region's wildlife resources. This implies that community engagement in conservation platforms is useful in sustainable management of Natural resources in the Society.

In Northern and Coastal Kenya, has inscription of Northern Rangelands Trust (NRT) in 2004, to serve the pastoral community with membership for social-political marginalized society [6]. Therefore, NRT acts as a conservation hub for community participation in biodiversity deliverables and also strengthens women led priorities in conservancy design, implementation and management.

However, in the Northern corridors the women efforts to participate in the conservancy management has been halted by erratic rains as invariable problem to livestock production systems in the region' s economic base [7]. Alternatively, there has been paradigm shifts in Wildlife Management from government institutions to enhance community participation through providing stability in conservancy, employment opportunities, enhance gender equity and investment in an area historically neglected.

Wildlife conservation has impacted communities in Zimbabwe to a tune of $56 \%$ under a programme titled CAMPFIRE which prioritized farmers as private entity to utilize wildlife resources on their own land until 1982 through Appropriate Authority (AA) pathways [8]. Therefore, the statistics are crucial for African Authorities to plan well on wildlife conservancy, enhance gender equity in Natural resource management, allocate budget well for the community and utilize the neglected communal lands for wildlife value.

In Namibia, studies have observed that Community-based natural resource management was initiated in the 1980s Integrated Rural communities into ambassadors for conservation of Nature with vision to reduce wildlife trafficking, embrace internal tourism, and finally enhance community participation in game reserves [9]. The local tourism is essential in enhancing gender mainstreaming through capacity building in community conservancy and create sustainable income for the women population in Africa.

In Marsabit County, Community leaders have leveraged on women as a human resource for golden job opportunities in projects as such livestock investments and beadworks as financial empowerment enterprises [10]. Significantly, the local conservation units such as Jaldesa, Sera and BiliqoBulesa community conservancies under Northern Rangelands Trust umbrella have elected women in conservancy leadership positions.

\section{A. Statement of the Problem}

Biodiversity conservation is a new paradigm shift in the management of Community wildlife resources as a tool to sustainable growth of the economy, improved livelihood, and preservation of nature. Panwar et al. [11] in India observed the role of women in promoting the values for environmental conservation. The $21^{\text {st }}$ Century pragmatic literature presents critical issues such as ecological changes, and segregation in social classes which are icon for breeding communal conflict on depleted natural resources. In their effort to enhance gender sensitivity for wildlife conservancy in Marsabit County, Kenya Jaldesa community women have faced setbacks such as lack of capacity building platforms, lack of Access \& Control of Resources, low decision making, inadequate Resource contribution and poor project Sustainability. However, Olalekan, et al [12] revealed close association between women and natural resources in rural areas while Naganag [13] identified vital role of women in conservation of sustainable eco-system.

These studies did not focus on role of women in community conservancy. Therefore, the current study fills the gap by establishing the role of women participation on sustainable wildlife conservation in Marsabit County, Kenya.

\section{B. Research Objectives}

This study sought to establish the influence of women participation on sustainability of the community conservation project implemented by Jaldesa Community Conservancy in Marsabit County, Kenya.

\section{LITERATURE REVIEW}

\section{A. Sustainability of Community Conservation Projects}

Sustainability based on [14] necessitate approach to project lifespan while [15], asserts that sustainability refers to addressing continuity of explicit program mechanism, increase community potential, framework for program operation and enhance capacity building of project staff. Critically, [16] discussed sustainable projects as clustering needs of citizens based on urgency and social differentiation while [17] supports that community participation forms part of project beneficiary selection process and it is decisive in the sustainability of any project. Therefore, community participation enhances women's ability to assume their role as benefactors in the project thus sustainability.

In other discourse [18] posits that improving local peoples' well-being, particularly in the rural tropics, can enhance environmental sustainability because local communities are stewards of natural resources that secure their livelihoods. [19] Confirms that the Lease for Wildlife Conservation program was initiated as a foundation for Wildlife has sustainably enhanced wildlife movement from Nairobi Park to Kitengela and Athi hills wildlife rescue centre. Nevertheless, distinct resources are locally assembled to uphold the women group projects for either success or failure in wildlife conservancy under Jaldesa community of Marsabit County, Kenya.

In Kenya, the experts in conservation of wildlife resources have designed a model for provision of capital to rangeland communities such as the Samburu community, Borana Community and the Maasai community also adopted at Jaldesa Community conservancy to enhance sustainability of such projects. However, [20] critics that projects in Africa operate based on donor funding which limits sustainability of 
such projects due to inadequate capital development. The huge funding of conservancy projects in Africa limits the community to meet the capital threshold for asset build-up to support the projects in the absence of donors.

\section{B. Women Involvement in Decision Making and} Sustainability of Community Conservation Projects

Across the globe, women are heavily involved in the environmental sector calls for global face value of women in green sectors of the economy such as fisheries, environment, agro-forestry and agriculture as a tool to control changes in climate whereas, [21] posits that duty to protect the ecology is a solemn decision to adopt inexpensive and clean energy technologies void of pollution to ecosystem. Study by [22] presents women as a participatory pillar to making decisions in environment protection and how to overcome challenges faced by their families in the ecological wellness. Therefore, environmental protection is a decision that women can consider and uphold sustainability of wildlife projects.

In another study, [23] discusses that female gender have less voice in national and international socio-political decisions thus impact on their unmet needs and poor income resilience. However, [24] observed that community utilization contributes to forest sustainability in Thailand. While [25] \& [26] concluded that the continuation of inequalities between social and economic livelihood in the society gender inequality within community limits women participation in project development. Therefore, it is imperative for women's voices to spearhead decisions making in the community projects more so conservancy projects in Jaldesa Marsabit County, Kenya.

\section{Women Participation, Implementation and} Sustainability of the Project

Resource contribution for implementation of projects involves, acquiring monetary resources, human resources, material resources, community contribution, membership, accountability and transparency, financial accounting, and management [27] \& [28]. The types and amount of physical resources women groups have greatly affected performance of such projects in Marsabit County, Kenya.

According to [29] several factors have been identified to be liable for poor sustainability such as poor project management control team and also foreign menace whereas Insufficient financing to implement project prevents it from ability to be sustainable [30]. However, the ability of a project to be sustained can be linked to numerous ways of funding. [31] Suggest that local resources have to be developed for enhanced sustainability especially when the donors cease to support external funding, in case funding delays or even when the external funding is inadequate.

D. Access \&Control of Resources by Women and Sustainability of Community Conservation Projects

In Africa, rights to factors of production are gendered with an extensive contact and organize economic resources authority, and political presence. The costs of inequalities in the society are always in custody of female gender [32]. Unfortunately, in Kenya and especially rural Kenya, women have little access and sometimes no control over resources and this inadequacy hinders women participation in resource management for development.
The daily activities performed by Women such as farming, fishing, sea food operation and harvesting gives them a solemn role to interact and protect the environment [33]. The society has low recognition to women's achievements towards management of nature through unpaid benefits, low economic value, and finally low powers to safeguard the environment.

[34] Argues that female have generally experienced greater restrictions, particularly on independent ownership and access to land. These challenges arise from different gender roles, rights, access, and control to natural resources of women and men, access to news and know-how related to reserve control where plans are to enrich male gender and traditional norms become a great cause of women being absent in resource management decision making processes at all levels.

\section{E. Capacity Empowerment for Women and Sustainability of Community Conservation Projects}

Capacity empowerment consists of persons, entities and communities who have capability to achieve their set goals over time. Apparatus for enhancing capacity in a project include technology, policies, framework, methodology, morals, capital, and authority that combine to manage the political and management class [35]. Social empowerment is a level ground for all gender as single development stakeholders. In another study, [36] posits that campaigns on gender matters among all benefactors are crucial for communities at the bedrock, government officers and activists with a national composition.

[37] Observed that environmental conservation is limited to women participation in project design and instruction with aim for wildlife value addition in India. Therefore, women need to be empowered to take active role in conservation of wildlife resources.

\section{F. Theoretical Framework}

The study adopted Participatory Theory and Ecological Feminism Theories. The participatory theory was postulated in 1993 by Putnam with view to promote citizens' including women involvement in decision making process. However, [38] critics Putman's theory that civil society is only useful in normative or polemical context while [39] argues that inequity in decision-making, access \& control of resources, implementation, and capacity building, negatively impact projects and their sustainability. The theory is pertinent in the study as a means to foster common destiny in the society such as women participation in wildlife conservation at Jaldesa conservancy in Marsabit County, Kenya.

The Ecological Feminism Theories roots their theoretical underpinning from a French feminist Françoise d'Eaubonne in 1974. Eco feminism expounds on environmentalism, and the relationship between women and the earth, as foundational to its analysis and practice. Further, a woman participation is directly opposite to biodiversity control and presence of female gender in the ecology has advanced ecological destruction in the society while [40] argues that education on first-rate environmental behavior enhances individuals' sustainability to protect the ecology.

However, Warren's criticism of 1996 documents important contributions of creating post-patriarchal world views and liberating aspect of conservancy that will be integral in the 
project of "feminism and environment" and environmentalism. Therefore, the theory is to the sustainability of community conservation projects in Jaldesa Community Conservancy due to a more nurturing and caring role for women.

\section{G. Conceptual Framework}

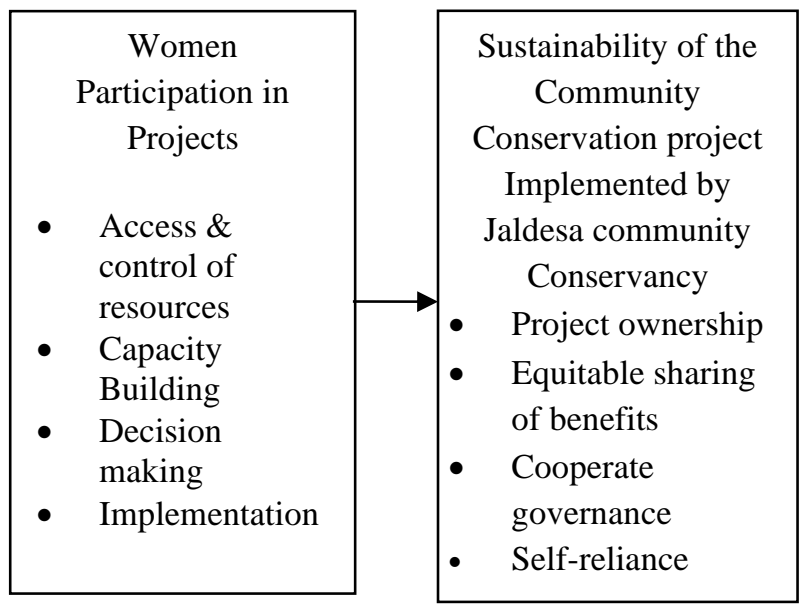

Fig. 1. Conceptual Framework.

\section{Methodology}

The design approach in the study was a cross-sectional survey having a mixed mode of research methods characterized with qualitative and quantitative. The Participatory and Ecological Feminism Theory were significant for the study. The probability and non-probability sampling were utilized to obtain sample size of 443 samples drawn from a target population of 19,860. Pilot study was obtained using a fraction of the sample. The reliability analysis was attained through Cronbach's Alpha coefficient of $\alpha>0.7$. The research instrument was utilized. The variables were measured using a five point Likert scale of equidistance of 0.5 ranging from Strongly Disagree (SD) $1<\mathrm{SD}<1.5$; Disagree (D) $1.5<\mathrm{D}<2.5$; Neutral (N) $2.5<\mathrm{N}<3.5$; Agree (A) $3.5<\mathrm{A}<4.5$; and Strongly Agree (SA) $4.5<\mathrm{SA}<5.0$. Content validity was realized through pilot testing results with comparison on objectives against the research instruments. Descriptively, statistics entailed dispersion, central tendency; frequency distributions and percentages whereas hypotheses were tested using inferential statistics. The relationship amid variables was established using Simple Regression Model. Objectively, results across variables were analyzed using statistical packages SPSS version 25. The data was then tabulated for presentation.

The data analysis was guided by the Pearson ran correlation to understand the correlation amid the variables and the indicators denoted as follows:

Dependent variable: Sustainability of the Community Conservation project Implemented by Jaldesa community Conservancy.

Independent Variable: (Access \& Control of Resources, Capacity Building, Decision Making, Implementation).

\section{FINDINGS AND DISCUSSIONS}

The statistics on demography for respondents are based on gender, age group, highest level of education, and Years involved in the conservancy were collected and results tabulated.

TABLE I: RESPONDENTS' GENDER

\begin{tabular}{ccc}
\hline & Frequency & Percent \\
\hline Male & 11 & 2.8 \\
Female & 378 & 97.2 \\
Total & 389 & 100.0 \\
\hline
\end{tabular}

The findings indicated that majority 378(97.2\%) were females and only $11(2.8 \%)$ were males. Women were majority because of the researcher's bias towards interviewing the female gender as the study involved women participation. Further, the females were available for interviews because of the nature of gender roles assigned to them.

\begin{tabular}{ccc}
\multicolumn{3}{c}{ TABLE II: RESPONDENTS' AGE BRACKET } \\
\hline & Frequency & Percent \\
\hline <25 years & 67 & 17.2 \\
26 - 35 years & 150 & 38.6 \\
36 - 45 years & 133 & 34.2 \\
46-55 years & 19 & 4.9 \\
<56 years & 20 & 5.1 \\
& 389 & 100.0 \\
\hline
\end{tabular}

Data on the age of the respondents indicated that respondents at age 26 and 35 years (38.6\%), $133(34 / 2 \%)$ were aged between 36 and 45 years while $39(10 \%)$ were aged above 46 years.

\begin{tabular}{ccc}
\multicolumn{3}{c}{ TABLE III: LEVELS OF EDUCATION } \\
\hline & Frequency & Percent \\
\hline Post Graduate & 13 & 3.3 \\
Undergraduate & 37 & 9.5 \\
Secondary & 28 & 7.2 \\
Primary & 47 & 12.1 \\
None & 264 & 67.9 \\
Total & 389 & 100.0 \\
\hline
\end{tabular}

The findings on level of education indicated that 264 $(67.9 \%)$ had not received any formal education. Forty-seven $(12.1 \%)$ had primary education, $28(7.2 \%)$ had secondary education. Only a small percentage of the respondents $9.5 \%$ and $3.3 \%$ were graduates and post graduate education respectively. The reason as to why majority had no formal education could be attributed to their lifestyle of pastoralism and for the fact that illiteracy and poverty levels are still too high in Arid and Semi-arid regions of Kenya.

\begin{tabular}{ccc}
\multicolumn{3}{c}{ TABLE IV: YEARS IN CONSERVANCY } \\
\hline Years & Frequency & Percent \\
\hline Below 1 year & 41 & 10.5 \\
1-2 years & 92 & 23.7 \\
3-4 years & 194 & 49.9 \\
Above 5 years & 62 & 15.9 \\
Total & 389 & 100.0 \\
\hline
\end{tabular}

The findings indicated that 194 (59.9\%) had been involved in the conservancy for between 3 and 4 years, 92 (23.7\%) for between 1 and 2 years while $62(15.9 \%)$ had been involved for over 5 years. The data shows that most of the respondents had been involved in the conservancy for a considerable long 
time for them to provide information on participation of women in the community conservation project.

\begin{tabular}{ccc}
\multicolumn{3}{c}{ TABLE V: DISTRIBUTION BY WORK AREA } \\
\hline Years & Frequency & Percent \\
\hline Conservancy board & 20 & 5.1 \\
County Government & 4 & 1.0 \\
Government officials & 3 & 0.8 \\
Conservancy Partners & 6 & 1.5 \\
Women Respondents & 346 & 88.9 \\
Conservancy staff & 10 & 2.6 \\
Total & 389 & 100.0 \\
\hline
\end{tabular}

\begin{tabular}{|c|c|c|c|}
\hline $\begin{array}{c}\text { Variables' } \\
\text { relationship }\end{array}$ & & Implementation & $\begin{array}{c}\text { Sustainability } \\
\text { of project }\end{array}$ \\
\hline \multirow{3}{*}{$\begin{array}{l}\text { Participation in } \\
\text { implementation }\end{array}$} & Pearson Correlation & 1 & $0.711 * *$ \\
\hline & Sig. (2-tailed) & & 000 \\
\hline & $\mathrm{N}$ & 389 & 389 \\
\hline \multirow{3}{*}{$\begin{array}{c}\text { Sustainability of } \\
\text { project }\end{array}$} & Pearson Correlation & $0.711 * *$ & 1 \\
\hline & Sig. (2-tailed) & 0.000 & \\
\hline & $\mathrm{N}$ & 389 & 389 \\
\hline
\end{tabular}

**. Correlation is significant at the 0.01 level (2-tailed).

The results depict that the Pearson correlation coefficient, $r$, is $0.711, n$ $=389$ and that it is statistically significant $(p=0.01)$. The correlation strongly and positively relates between access \& control of resources by women and sustainable conservation of Jaldesa community projects in Marsabit County, Kenya.

The findings depict that 346 of the respondents were women at $88.9 \%$. Others were respondents from the conservancy board of management $(5.1 \%)$, department in county government $(1 \%)$, government officials $(0.8 \%)$, conservancy partners $(1.5 \%)$ and staff members of the conservancy $(2.6 \%)$. The data shows that all the respondents were represented in the study sample.

\section{A. Descriptive Analysis for Sustainable Community Conservation Project}

Descriptive analysis was used to establish of Sustainability of conservancy projects. Outcomes presents composite mean as 3.652 with a Standard Deviation as 0.8425 . The statistics shows a greater extent of Sustainable conservancy projects in Jaldes community. The relationship amid variables was then established and level of influence for the last five years.

\section{B. Descriptive Analysis for Women Participation in Projects and Sustainable Jaldesa Community Conservation Project}

Descriptive analysis was done to determine the relationship between Women Participation in Projects (Access \& Control of Resources, Capacity Building, Decision Making and Implementation) and the Sustainable conservation of Jaldesa community wildlife. The results for access \& control of resources indicate a composite mean of 1.895 and a standard deviation of 0.7741 which implied a strong alliance between access \& control of resources and the Sustainable conservation of community conservancy in Jaldesa. The Composite Mean of 2.149, standard deviation of 0.8193 implied a significant influence between Decision Making and the Sustainability of the Community Conservation project Implemented by Jaldesa community Conservancy. The Composite Mean of 2.647, standard deviation of 0.6607 implied that the Implementation strongly influence the conservation of Jaldesa community projects. The Composite Mean of 3.788 and standard deviation of 0.8521 imply a positive relationship between Capacity Building strongly influence sustainable conservation of Jaldesa community projects.

To establish the correlation between Women Participation in Projects (Access \& Control of Resources, Capacity Building, Decision Making and Implementation) and the sustainable conservation of Jaldesa community projects in Marsabit County, Kenya Pearson's ran correlation coefficient was carried out.

C. Multiple Regression Results of Women Participation in Projects and the Sustainable Conservation of Jaldesa Community Projects in Marsabit County, Kenya

TABLE VII: PARTICIPATION IN DECISION MAKING

\begin{tabular}{|c|c|c|c|}
\hline $\begin{array}{l}\text { Variables' } \\
\text { relationship }\end{array}$ & & $\begin{array}{l}\text { Decision } \\
\text { Making }\end{array}$ & $\begin{array}{c}\text { Sustainability of } \\
\text { project }\end{array}$ \\
\hline \multirow{3}{*}{$\begin{array}{l}\text { Participation of } \\
\text { women in } \\
\text { decision making }\end{array}$} & $\begin{array}{c}\text { Pearson } \\
\text { Correlation }\end{array}$ & 1 & $0.774 * *$ \\
\hline & Sig. (2-tailed) & & 000 \\
\hline & $\mathrm{N}$ & 389 & 389 \\
\hline \multirow{3}{*}{$\begin{array}{l}\text { Sustainability of } \\
\text { project }\end{array}$} & $\begin{array}{c}\text { Pearson } \\
\text { Correlation }\end{array}$ & $0.774 * *$ & 1 \\
\hline & Sig. (2-tailed) & 0.000 & \\
\hline & $\mathrm{N}$ & 389 & 389 \\
\hline
\end{tabular}

**. Correlation is significant at 0.01 level (2-tailed).

The study observed that the Pearson ran correlation coefficient, $r$, is 0.774 , and that it is statistically significant ( $p$ $=0.01$ ). Therefore, there was a significant and positive relationship between participation of women in decision making and sustainable conservation of Jaldesa community projects in Marsabit County, Kenya. This implies that decision-making was associated with the level of sustainability of Jaldesa community conservation project.

TABLE VIII: PARTICIPATION IN IMPLEMENTATION

\begin{tabular}{cccc}
\hline \multicolumn{4}{c}{ TABLE VIII: PARTICIPATION IN IMPLEMENTATION } \\
\hline $\begin{array}{c}\text { Variables' } \\
\text { relationship }\end{array}$ & Implementation & $\begin{array}{c}\text { Sustainability } \\
\text { of project }\end{array}$ \\
\hline $\begin{array}{c}\text { Participation in } \\
\text { implementation }\end{array}$ & $\begin{array}{c}\text { Pearson } \\
\text { Correlation }\end{array}$ & 1 & $0.712 * *$ \\
& Sig. (2-tailed) & N \\
Pearson & Correlation & 389 & 000 \\
Sustainability of & $0.712 * *$ & 389 \\
project & Sig. (2-tailed) & 0.000 & 1 \\
& $\mathrm{~N}$ & 389 & 389 \\
\hline$* *$ Correlation is significant at the 0.01 level (2-tailed)
\end{tabular}

**. Correlation is significant at the 0.01 level (2-tailed).

The results showed that the Pearson correlation coefficient, $r$, was $0.71, n=389$ and that it is statistically significant $(p=0.01)$. The correlation was a strong and positive relationship between participation in implementation and sustainability of the community conservation project. Therefore, Levels of sustainable conservation of Jaldesa community projects in Marsabit County, Kenya were associated with higher levels of women participation in implementation of projects.

\begin{tabular}{|c|c|c|c|}
\hline $\begin{array}{l}\text { Variables' } \\
\text { relationship }\end{array}$ & & $\begin{array}{l}\text { Capacity } \\
\text { building }\end{array}$ & $\begin{array}{c}\text { Sustainability } \\
\text { ofproject }\end{array}$ \\
\hline \multirow{3}{*}{$\begin{array}{c}\text { Women } \\
\text { participation in } \\
\text { capacity building }\end{array}$} & $\begin{array}{c}\text { Pearson } \\
\text { Correlation }\end{array}$ & 1 & $0.765 * *$ \\
\hline & Sig. (2-tailed) & & 000 \\
\hline & $\mathrm{N}$ & 389 & 389 \\
\hline \multirow{3}{*}{$\begin{array}{c}\text { Sustainability of } \\
\text { the community } \\
\text { conservation } \\
\text { project }\end{array}$} & $\begin{array}{c}\text { Pearson } \\
\text { Correlation }\end{array}$ & $0.765 * *$ & 1 \\
\hline & Sig. (2-tailed) & 0.000 & \\
\hline & $\mathrm{N}$ & 389 & 389 \\
\hline
\end{tabular}


The Pearson correlation coefficient, $r$, is $0.765, n=389$ and that it is statistically significant $(p=0.01)$. The results explain that the women participation in capacity building is vital in sustainability of the community conservation project and the better they function the greater the chance of successful sustainability in Projects.

\section{CONCLUSION AND RECOMMENDATIONS}

The study determined the influence of Women Participation and the sustainable conservation of Jaldesa community projects in Marsabit County, Kenya. From the findings, it can be concluded that Access \& Control of Resources, Capacity Building, Decision Making and Implementation has a significant influence on the sustainable conservation of Jaldesa community projects in Marsabit County, Kenya and there is a strong relationship. This study concludes that appropriate participation of Women is important to promote Sustainability of the Community Conservation project. The study recommends that the authorities at national and county government at Marsabit County should involve women in decision making through equity representation in leadership roles, attend meeting, be party to decisions made by the conservancy board and making them well versed on the decision-making processes. Also, recommends that women manage, control, and have full access to resources through financial liberty, have voice on access to and control of resources and giving them right to resources and ownership. The study also recommends for sustainable capacity building for women through women participation in workshops to train on wildlife conservation, providing them with skills, systems, structures, processes values in sustainable community Wildlife project and conservation platforms. The study also recommends for a clear role of women in the implementation framework of the Conservancy projects for sustainable women empowerment in the society.

\section{ACKNOWLEDGMENT}

My deepest and sincere gratitude goes to Conservation International (CI) for funding my research project through a fellowship and most sincerely to Kame Westerman of CI, who has been a constant guide and support. Furthermore, my gratitude goes to Jaldesa community Conservancy, National Government Ministry of Tourism \& Wildlife officials, and County Government of Marsabit officials from the ministry of Tourism \& Wildlife for their irresistible support to retort to Questionnaires. I also, extend my heartfelt thanks to my mother Halaku, who has always believed in me as a star in whatever I do, and I could not fail her. Furthermore, my friend Ture Boru who kept encouraging me when burning the midnight oil got me weary and demotivated, I am forever indebted. Humble gratitude to my fellow ODEL students in Isiolo, George Ndege, Galgallo Sori and Silas Dennis Barasa just to mention a few for their encouragement and always willing to listen when consulted. Finally, I wish to acknowledge The University of Nairobi ICT for enabling elibrary support and the online processes with special mention to Celina Kaari (UON Isiolo ODEL Administrator) for her patience and swift coordination for all activities.

\section{REFERENCES}

[1] Wilson, E. O. (1992). The Diversity of Live. The Penguin Press, London.

[2] Terry, G. (2009). No climate justice without gender justice: an overview of the issues. Gender \& Development, 17(1), 5-18.

[3] Kenya Wildlife Service (2019), Kenya Wildlife Service: A Policy Framework and Development Programme, KWS, Nairobi.

[4] Jill, M. (2008). An Assessment of Local Peoples' Opinions of Community Conservation Initiatives in Relation to Livelihood Strategies in Kenya. University of Nebraska at Lincoln.

[5] Mburu, J. (2003). Factors Influencing Landowners' Participation in Wildlife Co-Management in Kenya. pp 1-29.

[6] Kenya Wildlife Service (2019), Kenya Wildlife Service: A Policy Framework and Development Programme, KWS, Nairobi.

[7] Kenya Wildlife Service (2019), Kenya Wildlife Service: A Policy Framework and Development Programme, KWS, Nairobi.

[8] Gujadhur, T., (2000). Organisations and their approaches in Community-based Natural Resource Management in Botswana, Namibia, Zambia and Zimbabwe, Occasional Paper.

[9] Gujadhur, T., (2000). Organisations and their approaches in Community-based Natural Resource Management in Botswana, Namibia, Zambia and Zimbabwe, Occasional Paper.

[10] Kenya Wildlife Service (2019), Kenya Wildlife Service: A Policy Framework and Development Programme, KWS, Nairobi.

[11] Panwar, N. L., Kaushik, S. C., \& Kothari, S. (2011). Role of renewable energy sources in environmental protection: A review. Renewable and sustainable energy reviews, 15(3), 1513-1524.

[12] Olalekan R. M.;Oyinlola B. O. Olalekan, A. Z.; Halimat. A. (2019). Women Contributions to Sustainable Environments in Nigeria. Journal of Scientific Research in Allied Sciences ISSN NO. 2455-5800 DOI No.10.26838/JUSRES.2019.5.4.104.

[13] Naganag, E. M. (2014). The role of indigenous women in forest conservation in upland Kalinga Province, Northern Philippines. Int. J. Adv. Res. Manag. Soc. Sci., 3 (6) (2014), pp. 75-89.

[14] Western, D.; Wright, R.M. (2016). Natural Connections: Perspectives in Community-based Conservation. Island Press, Washington, DC.

[15] Gruen, R.L.; Elliott, J.H.; Nolan, M.L.; Lawton, P.D.; Parkhill, A.; McLaren, C.J.; Lavis, J.N. (2018). Sustainability science: An integrated approach for health-programme planning. Lancet 372, 1579-1589.

[16] Kikwatha R.W (2017) Project beneficiary process and sustainability of dairy goat projects in Kenya, International Journal of Research \& Innovation Vol.6 pp. 146-148.

[17] Barasa, S. D., \& Kikwatha, R. W. (2020). Influence of Project Design Factors on Performance of Green Technology Market Projects in Meru County, Kenya. European Journal of Business and Management Research, 5(6). https://doi.org/10.24018/ejbmr.2020.5.6.582.

[18] Colchester, M. (2004). Conservation policy and indigenous peoples. Environmental Science \& Policy 7: 145-153.

[19] Mavoko, M. (2013). Resource mobilization for NGOs in the developing. London: Adonis and Abbet Publishers Limited.

[20] Kikwatha R.W (2017) Project beneficiary process and sustainability of dairy goat projects in Kenya, International Journal of Research \& Innovation Vol.6 pp. 146-148.

[21] Barasa, S. D., \& Kikwatha, R. W. (2020). Influence of Project Design Factors on Performance of Green Technology Market Projects in Meru County, Kenya. European Journal of Business and Management Research, 5(6). https://doi.org/10.24018/ejbmr.2020.5.6.582.

[22] Aguilar, M. (2012). Forest peoples, customary use and state forests: the case for reform. Forest People's Programme, Oxford, UK.

[23] Philipsson, J., Rege, J. E. O., Zonabend König, E., \&OkeyoMwai, A. (2011). Sustainable breeding programmes for tropical low-and medium input farming systems.

[24] Benjamin, A. (2010). Women in community forestry organizations: An empirical study in Thailand. Scandinavian Journal of Forest Research, 25(sup9), 62-68. doi: 10.1080/02827581.2010.506974.

[25] Adhikari, B., Di Falco, S., \& Lovett, J. C. (2004). Household characteristics and forest dependency: evidence from common property forest management in Nepal. Ecological economics, 48(2), 245-257.

[26] Baland, J. M., Gaspart, F., Platteau, J. P., \& Place, F. (2007). The distributive impact of land markets in Uganda. Economic Development and Cultural Change, 55(2), 283-311.

[27] Kikwatha R.W (2017) Project beneficiary process and sustainability of dairy goat projects in Kenya, International Journal of Research \& Innovation Vol.6 pp. 146-148. 
[28] Barasa, S. D., \& Kikwatha, R. W. (2020). Influence of Project Design Factors on Performance of Green Technology Market Projects in Meru County, Kenya. European Journal of Business and Management Research, 5(6). https://doi.org/10.24018/ejbmr.2020.5.6.582.

[29] Owino, P., Towet, G., Kirui, \&Luvega,. (2015). The Dilema in Sustainability of Community Based Projects in Kenya. Global Journal of Advanced Research, 2(4).

[30] Bamberger, L and Cheema, L (2010). Human Resource Management a Contemporary Approach, 4th edition. Harlow: Prentice Hall.

[31] Holder, H.D.; Moore, R.S. (2000). Institutionalization of community action projects to reduce alcohol use and related problems: Systematic facilitators. Subst. Use Misuse 2000, 35, 75-86. [CrossRef] [PubMed] 59.

[32] World Bank Report (2001)

[33] Barrow, E. \& M. Murphree (2001), Community conservation: From concept to practice.

[34] Gruen, R.L.; Elliott, J.H.; Nolan, M.L.; Lawton, P.D.; Parkhill, A.; McLaren, C.J.; Lavis, J.N. (2018). Sustainability science: An integrated approach for health-programme planning. Lancet 372, 1579-1589.

[35] DeMiglio, L.; Williams, A.M. (2013). A qualitative study examining the sustainability of shared care in the delivery of palliative care services in the community. BMC Palliat.

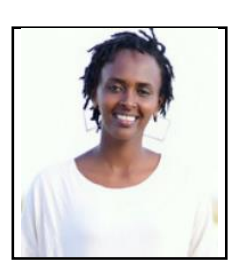

Ms Rufo Roba was born in Marsabit County, Kenya. She holds a Masters of Arts degree in Project Planning and Management from University of Nairobi.He also holds a Bachelor of Arts degree in Communication \& Media studies from Laikipia University, Kenya. Ms Rufo Roba has over 4 years of experience in communication and project planning \& management currently at Northern Rangelands. Also, she was a Conservation international fellow in 2019/2020 She is a specialist in developing communications strategies, crisis communications, website and social media content development, public and media relations and photography/videography on UjuziManyattani, Grass for future (Fodder banks) and the Northern Rangelands SACCO. She designed The Big North website (a Tourism Destination Management and Marketing for Northern Kenya)-www.thebignorth.travel.

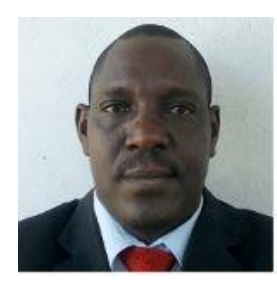

Dr Reuben Kikwatha was born in Kitui County, Kenya in 1975. He holds a doctorate in Project planning and Management, specializing in Project Planning Design, and Implementation from the University of Nairobi. He also holds a Masters degree in Project Planning and Management from The University of Nairobi, Bachelor's degree in Sociology from Moi University and a post graduate diploma in Community development.

Dr Kikwatha is currently a lecturer at the University of Nairobi, teaching project planning and Management in Open, Distance and eLearning (ODeL) campus, He has over 20 years of experience implementing Wildlife Conservation and community development projects in different parts of Kenya. Dr Kikwatha is a member of Kenya Association of Project Managers (KAPM) and Kenya Association of Fundraisers (KAF). He is also a member of different community development forums and academic mentorship groups. 